\title{
Measurement of serum amyloid A protein concentrations as test of renal allograft rejection in patients with initially non-functioning grafts
}

\author{
C P J MAURY, A-M TEPPO, J AHONEN, E v WILLEBRAND
}

\begin{abstract}
Serum amyloid A protein concentrations were monitored in 10 renal transplant recipients who required dialysis after transplantation because of an initially non-functioning graft. Fifteen rejection episodes were identified by repeated fine needle aspiration biopsies of the grafts. All rejections were characterised by pronounced increases in serum amyloid $A$ concentrations, the mean peak value being 363 (SE 57) $\mathrm{mg} / 1$ as compared with a mean preoperative concentration of 14 (5) $\mathrm{mg} / \mathrm{l}$. The rise in concentrations preceded the start of antirejection treatment by an average of 2.5 days in eight of the rejection episodes, in five episodes it occurred the same day, and in two episodes it occurred the next day. With exclusion of the predictable surgery induced rise in values, which peaked on the second postoperative day, there were 17 increases in amyloid $A$ concentrations peaking at $\geqslant 100 \mathrm{mg} / 1$; in two cases they were not related to documented rejection.

These findings show that measurements of serum amyloid $A$ concentration provide a valuable non-invasive aid in identifying acute renal allograft rejection, including that in patients whose graft does not function initially.
\end{abstract}

\section{Introduction}

Identifying rejection of renal transplants in patients with acute tubular necrosis of the graft presents a major diagnostic difficulty. Tests of renal function cannot be used and the only practical aid in the diagnosis is histological or fine needle aspiration biopsy of the graft. We have observed that acute renal allograft rejection induces a dramatic increase in the serum amyloid A protein concentration in $\operatorname{man}^{1}$ and that monitoring the serum amyloid A concentration in the postgrafting period provides a sensitive means of detecting rejection of the graft. ${ }^{2}$ Our data further suggested that the test might be applied in transplant recipients requiring haemodialysis in the postgrafting period. We have now evaluated that question more closely and present our findings.

\section{Patients and methods}

During September to December 1982 serum samples for measurement of serum amyloid A concentrations were collected daily from all

Fourth Department of Medicine, University of Helsinki, Finland C P J MAURY, MD, assistant professor of medicine A-M TEPPO, MSC, clinical chemist

Fourth Department of Surgery, University of Helsinki J AHONFN, MD, head surgeon, transplantation unit E v WILLEBRAND, MD, lecturer in immunology, transplantation laboratory

Correspondence to: Dr Peter Maury, Fourth Department of Medicine, University of Helsinki, SF-00170 Helsinki 17, Finland. recipients of cadaveric renal transplants during their stay at the renal transplantation unit of the Fourth Department of Surgery, University Central Hospital, Helsinki. During that period 10 recipients (seven women, three men; mean age 39 years, range 25-62) required dialysis (haemodialysis, eight patients; peritoneal dialysis, two patients) in the immediate postgrafting period because of a nonfunctioning graft. Mean preoperative urine excretion was $275 \mathrm{ml} /$ 24 hours (range $0-500 \mathrm{ml} / 24$ hours), and mean preoperative serum creatinine concentration was $936 \mu \mathrm{mol} / 1(10.6 \mathrm{mg} / 100 \mathrm{ml})$ (range $699-1511 \mu \mathrm{mol} / 1 ; 7 \cdot 9-17 \cdot 1 \mathrm{mg} / 100 \mathrm{ml}$ ). In one case the transplant was removed because of irreversible rejection. The other nine patients were discharged from hospital with a functioning graft, their mean urine excretion being $3484 \mathrm{ml} / 24$ hours (range 2310-4690 $\mathrm{ml} / 24$ hours) and mean serum creatinine concentration $262 \mu \mathrm{mol} / 1$ (3.0 mg/100 ml) (range $91-573 \mu \mathrm{mol} / 1 ; 1.0-6.5 \mathrm{mg} / 100 \mathrm{ml}$ ).

Six of the patients had chronic glomerulonephritis as their underlying disease, two diabetic nephropathy, one chronic pyelonephritis, and one amyloidosis associated with rheumatoid arthritis. Mean time of cold ischaemia of the cadaveric allografts was 33 hours (range 28-43 hours). Diagnosis of rejection was based on the cytological findings in fine needle aspiration biopsy specimens. ${ }^{34}$ Altogether 100 aspiration biopsies were performed, and in one case histological graft biopsy was also performed. The results of the serum amyloid A assay were not utilised at the time of clinical diagnosis of rejection and start of antirejection treatment. The main immunosuppressive agents used were azathioprine and methylprednisolone. ${ }^{25}$ Episodes of rejection were managed by increasing the oral dosage of methylprednisolone. ${ }^{25}$

Serum amyloid $\mathrm{A}$ concentration was measured by single radial immunodiffusion using amyloid A antiserum (Atlantic Antibodies, USA). Purified amyloid A protein was used as standard. The plates were incubated for two hours at $37^{\circ} \mathrm{C}$, then kept at room temperature. Preliminary results (which indicate whether the concentration will rise above $100 \mathrm{mg} / \mathrm{l}$ ) were read after six hours; definitive results were usually read next morning.

\section{Results}

Fifteen episodes of rejection occurred as documented by positive fine needle aspiration cytology. All the rejections were characterised by pronounced increases in serum amyloid A concentrations (peaking at $\geqslant 100 \mathrm{mg} / \mathrm{l})$. The mean peak concentration during the rejections was 363 (SE 57) $\mathrm{mg} / \mathrm{l}$. There were no false negative readings, so that the sensitivity of the serum amyloid A test was $100 \%$. The rise in concentration preceded antirejection treatment in eight of the 15 instances by an average of 2.5 days (range one to five days); in five instances it occurred the same day, and in two instances it occurred the next day.

In these patients-all of whom remained anuric or oliguric postoperatively-surgery induced an increase in the serum amyloid A concentration which was kinetically similar to that seen in patients with a functioning graft. Values increased from a mean of 14 (SE 5) $\mathrm{mg} / \mathrm{l}$ before operation to a peak of $248(50) \mathrm{mg} / \mathrm{l}$ on the second postoperative day and levelled off rapidly. With the exclusion of these predictable rises in the immediate postoperative period there were 17 increases in concentrations peaking at the arbitrarily chosen value of $\geqslant 100 \mathrm{mg} / 1 ; 15$ of these occurred concurrently with rejection of the allograft, so that the predictive value of the serum amyloid A test was $88 \%$. The one false positive result was caused by a subcutaneous wound infection, while the cause of the other remained unexplained.

The figure shows the course in a patient requiring haemodialysis for more than three weeks postoperatively. In this patient the first 
rise in serum amyloid $A$ concentration was induced by surgery. It was followed by a diphasic rise, peaking on days 9-10 and 13 . Transplant aspiration biopsy showed clear evidence of allograft rejection on the 12th postoperative day and antirejection treatment was therefore instituted. After a polyuric phase during the fifth postoperative week graft function stabilised.
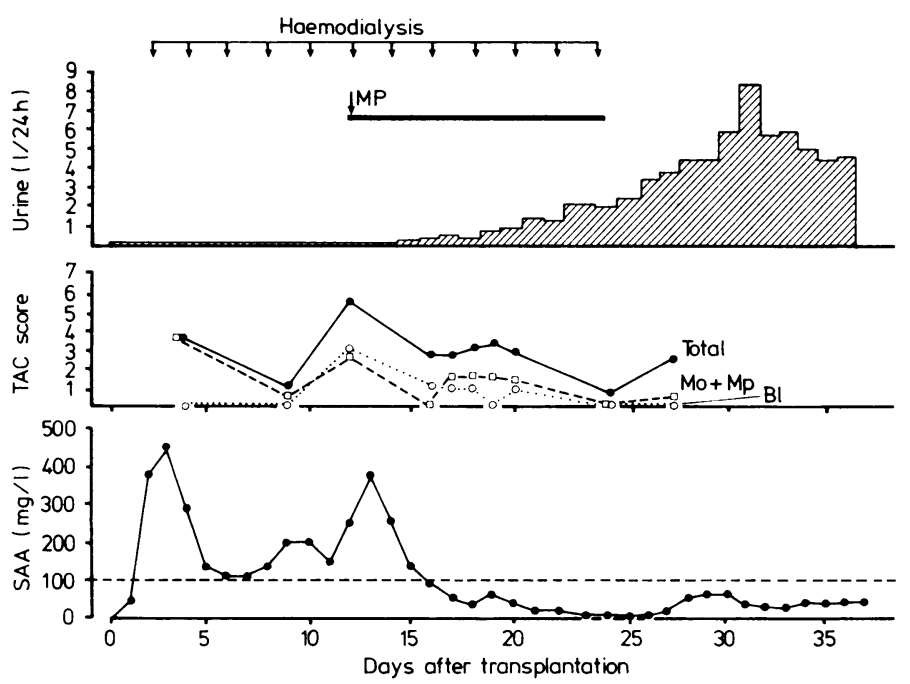

Urine excretion, transplant aspiration cytology (TAC) scores, ${ }^{4}$ and serum amyloid A protein (SAA) concentrations after renal transplantation in 55 year old man who had developed renal failure and severe hypertension as result of chronic glomerulonephritis. Patient underwent bilateral nephrectomy one year before transplantation.

$\mathrm{MP}=$ Antirejection treatment with oral methylprednisolone. Mo= Monocyte, $\mathrm{Mp}=$ macrophage, $\mathrm{Bl}=$ lymphoid blast score in TAC.

\section{Discussion}

Elsewhere we have shown that the serum concentration of amyloid $A$ increases dramatically in acute renal allograft rejection in man. ${ }^{12}$ Since dialysis has no significant effect on serum amyloid $\mathrm{A}^{2}$ and the concentration does not correlate with the degree of renal insufficiency ${ }^{6}$ we studied whether the serum amyloid A test might also be of help in diagnosing rejection in renal transplant recipients whose grafts do not function initially. A common cause of delayed function in cadaveric grafts is acute tubular necrosis. ${ }^{7}$ The diagnosis of hyperacute rejection and vascular complications is not usually difficult. In patients with acute tubular necrosis of the graft it is important to identify and treat concurrent acute rejections. Since laboratory tests that depend on renal function cannot be used, the diagnosis is chiefly based on histological or cytological biopsy studies. Our results show that monitoring the serum amyloid $\mathrm{A}$ concentration in the postgrafting period provides a new means of identifying and confirming acute allograft rejection in these cases.

Serum amyloid $\mathrm{A}$ is an acute phase reactant which is associated with high density lipoproteins in the circulation. ${ }^{8}$ Under normal conditions the serum amyloid A concentration is usually $<1 \mathrm{mg} / 1$ (range $<1-15 \mathrm{mg} / \mathrm{l}) .{ }^{9}$ In tissue injury and inflammation the concentration may rapidly increase by a factor of $100-1000 .^{10-12}$ Other studies have shown that macrophage factors, which are closely related to interleukin 1 , may induce hepatic synthesis of serum amyloid A. ${ }^{13-15}$

Since serum amyloid $\mathrm{A}$ is an acute phase protein an increase in the postgrafting period may imply both rejection and infection or surgical complication. We do not find the nonspecific nature of serum amyloid $\mathrm{A}$ a problem; a positive test result suggests the possibility of rejection and, in the absence of obvious infection or surgical complication, treatment may be started. Transplant aspiration biopsy may be used as a confirmatory test at that stage. A negative serum amyloid A test result-that is, no significant increase in concentration-on the other hand, argues strongly against rejection. ${ }^{2}$ The reproducibility of the measurement is high ${ }^{2}$ and the test is easily performed as a daily routine. It requires very small amounts of sample (10-20 $\mu \mathrm{l}$ serum), and preliminary results may be read after as little as six hours. The surgery induced rise in concentration peaking on the second postoperative day is predictable and does not complicate interpretation. ${ }^{1210}$ Since patients' baseline concentrations of serum amyloid A may vary postoperatively daily monitoring gives the best information. A rise in the concentration - not necessarily the absolute value-is thus the most important criterion. We, however, find a limit of $100 \mathrm{mg} / \mathrm{l}$ useful: if the concentration does not exceed that value an acute rejection is unlikely. The numerical value of the concentration depends on several methodological factors, including the standard used. Hence each laboratory must standardise the test on acute phase sera with known values.

The cost of providing the serum amyloid $\mathrm{A}$ test as a daily routine is difficult to estimate for different countries and laboratories and is largely determined by the source of the antiserum. Nevertheless, it takes only about 15 minutes of a technician's time, and we estimate the total cost as $£ 5-15$ per patient a day.

We conclude that monitoring the serum amyloid A concentration offers a valuable non-invasive aid in the early diagnosis of acute allograft rejection, including that in renal transplant recipients who remain anuric or oliguric in the postgrafting period.

The purified amyloid A protein used as standard was a gift from Dr B Skogen, Norway. We also thank Dr B Eklund and the nurses in the renal transplantation unit for their help and cooperation, and the Sigrid Jusélius Foundation for support.

\section{References}

${ }^{1}$ Maury CPJ, Teppo A-M, Eklund B, Häyry P, Ahonen J. Serum amyloid A levels in human renal allograft rejection. Clin Sci 1983;65:547-50.

${ }^{2}$ Maury CPJ, Teppo A-M, Eklund B, Ahonen J. Serum amyloid A protein: a sensitive indicator of renal allograft rejection in humans. Transplantation (in press)

${ }^{3}$ Pasternack A, Virolainen $M$, Häyry $P$. Fine needle aspiration biopsy in the diagnosis of human renal allograft rejection. F Urol 1973;109:167-72.

4 Häyry P, von Willebrand E. Monitoring of human renal allograft rejection with fine needle aspiration cytology. Scand 7 Immunol $1981 ; 13: 87-97$.

${ }^{5}$ Häyry $P$, von Willebrand $E$, Ahonen J, Eklund B. Glucocorticoids in renal transplantation. Scand f Immunol 1982;16:39-49.

${ }^{6}$ Falck HM, Maury CPJ, Teppo A-M, Wegelius O. Persistently high serum amyloid A protein and C-reactive protein levels correlate with rapid progression of secondary amyloidosis. $\mathrm{Br} \mathrm{MedF} \mathrm{1983;286:1391-3.}$

${ }^{7}$ Rossman P, Jirka J. Rejection nephropathy. Amsterdam: Elsevier/NorthHolland Biomedical Press, 1979:274-84

${ }^{8}$ Benditt EP, Eriksen N. Amyloid protein SAA is associated with high density lipoprotein from human serum. Proc Natl Acad Sci USA 1977;74:4025-8.

${ }^{9}$ Maury CPJ, Teppo A-M, Salaspuro MP. Amyloid A fibril degrading activity in liver disease-relation to serum acute phase and other protein levels. Clin Chim Acta 1983;131:29-37.

${ }^{10}$ Maury CPJ, Teppo A-M, Raunio P. The acute phase response and its relation to amyloid $A$ degrading activity in serum of patients with rheumatoid arthritis undergoing arthroplasty. Eur f Clin Invest 1983; 13:73-8.

$"$ McAdam KPWJ, Elin RJ, Siped, JD, Wolff SM. Changes in human serum amyloid $\mathrm{A}$ and $\mathrm{C}$-reactive protein following ethiocholanolone inflammation. 7 Clin Invest 1978;61:390-4.

12 deBeer FC, Mallya RK, Fagan EA, Lanham JG, Hughes GRV, Pepys MB. Serum amyloid $A$ protein concentration in inflammatory diseases and its relationship to the incidence of reactive systemic amyloidosis. Lancet 1982 ;ii:231-3.

13 Sipe JD, Vogel SN, Ryan JL, McAdam KPWJ, Rosenstreich DL. Detection of a mediator derived from endotoxin-stimulated macrophages that induces the acute phase serum amyloid $A$ response in mice. 7 Exp Med 1979;150:597-606.

${ }^{14}$ McAdam KPWJ, Li J, Knowles J, et al. The biology of SAA : identification of the inducer, in vitro synthesis, and heterogeneity demonstrated with monoclonal antibodies. Ann NY Acad Sci 1982;389:126-36.

15 Morrow JF, Stearman RS, Peltzman CG, Potter A. Induction of hepatic synthesis of serum amyloid A protein and actin. Proc Natl Acad Sci USA $1981 ; 78: 4718-22$.

(Accepted 10 November 1983) 